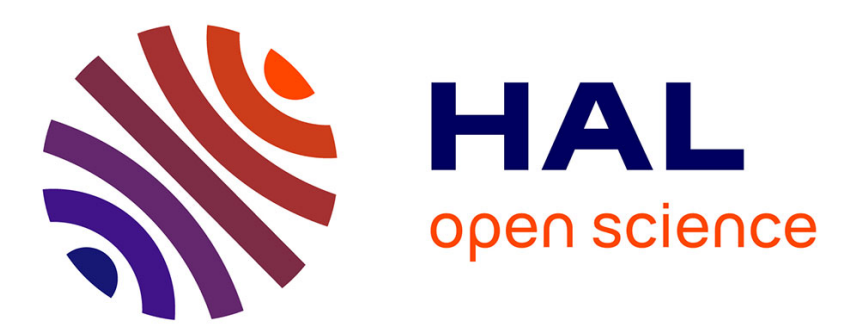

\title{
A bizarre sternorrhynchan wing from the Lower Jurassic of Luxembourg (Hemiptera: Sternorrhyncha: Pincombeomorpha?)
}

\author{
Jacek Szwedo, Robert Weis, André Nel
}

\section{- To cite this version:}

Jacek Szwedo, Robert Weis, André Nel. A bizarre sternorrhynchan wing from the Lower Jurassic of Luxembourg (Hemiptera: Sternorrhyncha: Pincombeomorpha?). Historical Biology, 2017, 31 (6), pp.806-812. 10.1080/08912963.2017.1395423 . hal-02374596

\section{HAL Id: hal-02374596 https://hal.sorbonne-universite.fr/hal-02374596}

Submitted on 21 Nov 2019

HAL is a multi-disciplinary open access archive for the deposit and dissemination of scientific research documents, whether they are published or not. The documents may come from teaching and research institutions in France or abroad, or from public or private research centers.
L'archive ouverte pluridisciplinaire HAL, est destinée au dépôt et à la diffusion de documents scientifiques de niveau recherche, publiés ou non, émanant des établissements d'enseignement et de recherche français ou étrangers, des laboratoires publics ou privés. 
Family Xulsigiidae is registered in Zoobank under the urn:Isid:zoobank.org:act:3A57B428-638A439A-AEC4-D18B5959B5CA

Genus Xulsigia is registered in Zoobank under the urn:Isid:zoobank.org:act:2B255A30-5A7C-4CF8AE77-18ED6E8E03C2

A bizarre sternorrhynchan wing from the Lower Jurassic of Luxembourg (Hemiptera: Sternorrhyncha: Pincombeomorpha?)

Jacek Szwedo ${ }^{\mathrm{a}}$, Robert Weis ${ }^{\mathrm{b}}$ and André $\mathrm{Nel}^{\mathrm{c}}$

${ }^{a}$ Department of Invertebrate Zoology, University of Gdańsk, 59, Wita Stwosza St., PL80-308

Gdańsk, Poland. [jacek.szwedo@biol.ug.edu.pl]

${ }^{b}$ Musée national d'histoire naturelle, Luxembourg, Section Paléontologie, 25, rue Münster L2160 Luxembourg, Grand-duché de Luxembourg. [rweis@mnhn.lu]

'Institut de Systématique, Évolution, Biodiversité, ISYEB - UMR 7205-CNRS, MNHN, UPMC, EPHE, Muséum national d'Histoire naturelle, Sorbonne Universités, 57, rue Cuvier, CP 50, Entomologie, F-75005, Paris, France.[anel@mnhn.fr]

Fossil wing of Hemiptera Sternorrhyncha with peculiar venation is described from the lower Toarcian (Lower Jurassic) of Bascharage (Grand-duchy of Luxembourg). It represents new family Xulsigiidae fam. nov., comprising a new genus and species Xulsigia karetsa gen. et sp. nov. It is placed preliminarily in extinct infraorder Pincombeomorpha for the presence of three branches of median vein. Key to families of Pincombeomorpha is given and the taxonomic position and venation features of the new fossil are discussed. 
Keywords: Pincombeomorpha; Xulsigiidae fam. nov.; Xulsigia karetsa gen. et sp. nov.; Toarcian; Luxembourg

\section{Introduction}

Sternorrhyncha Amyot \& Audinet-Serville, 1843 (Insecta: Hemiptera Linnaeus, 1758) is an old lineage of the Hemiptera appearing diversified in the fossil record in earliest Permian, with oldest Aphidomorpha Becker-Migdisova et Aizenberg, 1962, Pincombeomorpha Shcherbakov, 1990 and Psyllaeformia Verhoeff, 1893. The Pincombeomorpha is an extinct group, recorded in the Permian and Triassic, with three families (Shcherbakov 2007); the fossil described below is preliminary included to this infraorder, corresponding to the most recent record of the group.

The Lower Jurassic of Western Europe is characterized by several marine outcrops with thousands of fossil insects, especially in England, Germany, northern France, Belgium, and Luxembourg (Whalley 1985; Ansorge 1996, 2003; etc.). Among them, the entomofauna of the Bascharage area (Grand-duchy of Luxembourg) is exceptionally rich and diverse, although the outcrops opened by road and factory construction works are no longer accessible for study. This fauna comprises Odonata, Dictyoptera, Phasmatodea, Orthoptera, Amphiesmenoptera, Hemiptera, Neuroptera, Hymenoptera, Diptera, and Coleoptera (Fossilworks 2017). For the moment only single representative of the Hemiptera: Coleorrhyncha was described from this locality (Szwedo 2011). Here we present the first representative of Sternorrhyncha from the upper Lower Jurassic of the Grand-duchy of Luxembourg, describing a new family, genus and species for it. We also propose a new key to families of Pincombeomorpha.

\section{Geological setting and location}


The lower Toarcian (Lower Jurassic) sediments outcropping in the southern part of the Grand-duchy of Luxembourg are long renowned for their rich fossil content and excellent preservation (Dittrich 1993; Godefroit 1994), justifying their designation as KonservatLagerstätte. Preserved in a similar setting to the coeval Posidonienschiefer Formation of SouthWest Germany, these outcrops consist of bituminous black shales with intercalated nodular limestone beds that formed at an early diagenetic stage and thus permitted the preservation of delicate fossilized remains (Hanzo 1978, 1979; Henrotay et al. 1998). Rare insect remains have been known from the marine formations of the north-eastern Paris Basin since the $19^{\text {th }}$ century. Maubeuge (1973) first illustrated an odonatan forewing (a Heterophlebioidea erroneously attributed to the Protomyrmeleontidae) from the Grand-duchy of Luxembourg (Schouweiler site), followed by a report of Delsate et al. (1992) from the nearby Belgian Province of Luxembourg (Aubange site). Since then, several insects have been reported from different localities, with the best-known site Bascharage (Fig. 1) (Hermoso et al. 2014; Nel \& Weis 2017), where finds have been made during temporary construction works in the 'Bommelscheier' and 'Op Zaemer' industrial areas over the last 30 years. The specimen described herein was found in flat, laminated lenticular limestone (named LENT in Henrotay et al. 1998, fig. 2; named 'laminated limestone bed' in Hermoso et al. 2014, fig. 2) at the Bascharage "Bommelscheier" site in the early '90. Apart from insect remains, the lenticular limestone also yielded marine organisms such as rare cephalopods, arthropods, small fishes (Leptolepis a.o.), occasional marine reptile remains and rare land plants (Henrotay et al. 1998; Delsate et al. 1999).

\section{Material and methods}

Acronym: MNHNL (Musée national d'histoire naturelle, Luxembourg). Macrophotos taken at MNHNL using a Ricoh CX1 camera, with a Rodenstock 35mm f/4 Rodagon lense. The 
images were readjusted with CorelDraw and CorelPhoto-Paint X9 software package. We follow the wing venation nomenclature of Nel et al. (2012), with the following abbreviations: cubitus anterior $\mathrm{CuA}$; cubitus posterior $\mathrm{CuP}$; median posterior vein $\mathrm{MP}$; Pcu poscubital vein; radial anterior RA; radial posterior RP; subcostal posterior ScP.

\section{Systematic palaeontology}

\section{Key to families of Pincombeomorpha}

(timespan given in brackets; data not confirmed with described taxa in square brackets)

1. Basal cell (between $\mathrm{R}+\mathrm{MP}$ and $\mathrm{CuA}$ base) and crossvein $m$-cu present; RP forked; clavus with Y-vein Boreoscytidae Becker-Migdisova, 1949

(see Shcherbakov 2007: fig. 5) Permian (Kungurian-Roadian)

-. Basal cell, free $\mathrm{CuA}$ base and veinlet $m p-c u$ absent; RP simple or reduced; clavus with one simple vein

2. Veinlet $r-m p$ present; stem MP strong and convex up to nodal line; pterostigma small, narrow; claval vein $(\mathrm{Pcu})$ remote from posterior margin Pincombeidae Tillyard, 1922 (see Shcherbakov 2007: fig. 7) Permian (Changhsingian)-Triassic (Carnian)

—. Veinlet $r-m p$ absent; stem MP well developed, or fold-like before nodal line, or originating beyond it, or reduced; pterostigma enlarged

3. Branch RP originating well before pterostigma, but basad of branch $\mathrm{MP}_{1+2}$ forking; stem MP or fold-like before nodal line, or originating beyond it, or reduced; branch $\mathrm{CuA}_{1}$ much shorter than $\mathrm{CuA}$ stem; claval vein $(\mathrm{Pcu})$ remote from posterior margin

Simulaphididae Shcherbakov, 2007;

(see Shcherbakov 2007: fig. 9) Permian (Changhsingian)-[Triassic (Norian)] 
—. Branch RP originating well before pterostigma, but apicad of branch $\mathrm{MP}_{1+2}$ forking; stem MP well developed, branch $\mathrm{MP}_{3}$ captured by stem $\mathrm{CuA}$ at base; branch $\mathrm{CuA}_{1}$ longer than $\mathrm{CuA}$ stem; claval vein (Pcu) close to posterior margin Xulsigiidae fam. nov. Jurassic (lower Toarcian)

Order Hemiptera Linnaeus, 1758

Suborder Sternorrhyncha Amyot et Audinet-Serville, 1843

Clade Aphidiformes sensu Schlee, 1969 (= Aphidococca sensu Kluge, 2010) Infraorder Pincombeomorpha Shcherbakov, 1990

Family Xulsigiidae fam. nov.

Type genus. Xulsigia gen. nov.; here designated.

Diagnosis. Forewing characters only. Basal cell absent; stems of R, MP, and CuA fused at wing base, stem ScP slightly shifted then $\mathrm{ScP}$ adpressed and parallel to stem $\mathrm{R}(+\mathrm{MP}+\mathrm{CuA})$; pterostigma small, subapical, delimited posteriorly by ScP, and anteriorly by RA; branch RP originating well before pterostigma stem, RP forked terminally; stem MP well developed, MP with three branches, branch $\mathrm{MP}_{1+2}$ basally fused with radius but branch $\mathrm{MP}_{3}$ captured by stem $\mathrm{CuA}$ at base (apomorphy), $\mathrm{MP}_{1+2}$ forked apically; stem $\mathrm{CuA}$ shorter than common portion of stem $\mathrm{R}+\mathrm{M}_{1+2}$, branch $\mathrm{CuA}_{1}$ distinctly longer than stem $\mathrm{CuA}$; claval portion narrow, with single claval vein Pcu (apomorphy).

Included taxon. Only genus Xulsigia gen. nov.

Genus Xulsigia gen. nov.

Type species. Xulsigia karetsa sp. nov.; here designated. 
Diagnosis. Forewing characters only. Wing large (size comparable to the wings of Dinoscyta Shcherbakov, 2007, quite larger than those of the Simulaphididae); a very long areola postica. Etymology. After Xulsigiae, triple goddess of fertility of the worshipped at the healing-spring shrine in Augusta Treverorum (present-day Trier), close to the modern Luxembourg.

Xulsigia karetsa sp. nov.

(Figs 2-6)

Material. Holotype TV045 $(\mathrm{a}+\mathrm{b})$ (print and counterprint), stored at the Palaeontological collections of the MNHNL.

Diagnosis. As for genus; monotypic.

Etymology. Named after kar-etsā, kinswoman in proto-Celtic language.

Locality and horizon. "Couches à Harpoceras falciferum (lo1)", Lower Jurassic, lower Toarcian, Serpentinum (Falciferum) Chronozone (ca. $182.7 \mathrm{Ma}$ ), outcrop temporarily accessible (early '90) during the construction works of a factory at "Bommelschéier", Bascharage, Grand Duché du Luxembourg.

Description. Large Sternorrhyncha, with wingspan over $30 \mathrm{~mm}$. A complete forewing, 15.7 $\mathrm{mm}$ long, $3.6 \mathrm{~mm}$ wide, apparently hyaline, except for darker area between radius and costa; a weak simple subcostal vein, closely appressed to radius, ending on costa $13.3 \mathrm{~mm}$ from wing base; a strong radial vein from which a first strong convex vein $\mathrm{CuA}$ separates $2.1 \mathrm{~mm}$ from wing base; two simple and curved veins emerge anteriorly from straight stem of $\mathrm{CuA}$, of different shape, first one (interpreted as a basal branch of $\mathrm{M}$ ) is branching as a secondary vein from $\mathrm{CuA}$, with a faint furrow between it and main stem of $\mathrm{CuA}$ and more concave than the stem of $\mathrm{CuA}$; while second one is a true fork of $\mathrm{CuA}$; base of first vein $1.0 \mathrm{~mm}$ from base of $\mathrm{CuA}$, base of second anterior branch of $\mathrm{CuA} 1.7 \mathrm{~mm}$ distally; a second vein $\mathrm{M}$ emerges from radius $5.2 \mathrm{~mm}$ distal of base of $\mathrm{CuA}$, also more concave than stem of $\mathrm{CuA}$; this branch of $\mathrm{M}$ is 
divided into two simple branches $2.5 \mathrm{~mm}$ distally; a third vein RP emerges from radius $3.3 \mathrm{~mm}$ distal of base of M; RP is divided into two simple branches $2.6 \mathrm{~mm}$ distally; RA making a strong posterior curve $1.4 \mathrm{~mm}$ distal of base of RP, delimiting a pterostigma with distal end of ScP; wing base petiolate, very narrow, with a weak undulate vein $\mathrm{CuP}$ more or less parallel to $\mathrm{CuA}$ and one straight vein (postcubital vein) closely parallel to posterior wing margin.

\section{Discussion}

This wing can be attributed to the clade Acercaria (Miomoptera, Hypoperlida, Psocodea, Permopsocida, Thripida, Hemiptera) sensu Prokop et al. (2017) and more precisely to the Hemiptera: Sternorrhyncha because of the complete fusion of median and Cbitus anterior veins to radius at wing base, $\mathrm{MP}$ and $\mathrm{CuA}$ re-emerging more distally, and $\mathrm{CuP}$ is simple.

Convex $\mathrm{CuA}$ with curved anterior branches emerging from a straight stem is observed in some other insect groups, e.g. in the dictyopteran Palaeozoic Paoliida, some Protembiidae Tillyard, 1937 (i.e. Permian Sojanoraphidia Martynova, 1952), and the Lower Jurassic blattogryllid genus Dorniella Bode, 1953 (Storozhenko 1998, Prokop et al. 2014, Guan et al. 2015, Aristov 2015a, b). But these insects have numerous crossveins and, more important, their cubital and median veins are not basally fused with radius and re-emerging distally as in Xulsigia gen. nov. The 'orthopteroid' insects have a common stem $\mathrm{M}+\mathrm{CuA}$ reemerging from radius, unlike in Xulsigia and a complex branching of $\mathrm{CuP}$.

Xulsigia karetsa gen. et sp. nov. presents unambiguous set of characters placing it in clade Aphidiformes sensu Schlee, 1969 (= Aphidococca sensu Kluge 2010). Unfortunately there is still no phylogenetic analysis of this clade including fossil and extant taxa. Thus we are obliged to propose a provisional attribution based on shared similarities, rather than putative synapomorphies. Several features are shared with Aphidomorpha Becker-Migdisova et Aizenberg, 1962 (Shcherbakov 2007, Heie \& Wegierek 2009): (i) distinctly broad pterostigma, 
(ii) common $\mathrm{ScP}+\mathrm{R}+(\mathrm{MP})+\mathrm{CuA}$ stem, (iii) $\mathrm{MP}$ vein forked, (iv) absence of crossveins, (v) $\mathrm{RP}$ vein emerging a little basad of pterostigma, and (vi) ScP not extending into pterostigma. After the key of Shcherbakov (2007), the newly described Xulsigia karetsa falls near the Simulaphididae Shcherbakov, 2007 because of the following characters: basal cell absent (no cua-cup veinlet); crossvein $r-m$ absent; base of RP well basal of pterostigma. The Coccidomorpha, Naibioidea, and basal Aphidomorpha have a RP originating near or beyond the base of the pterostigma. Fossils of the extinct families Boreoscytidae and Pincombeidae (Pincombeomorpha) have crossveins, especially the cua-cup (plesiomorphic state, this vein is typically present in the ground plan of Paraneoptera, see Nel et al. 2012; Huang et al. 2016; Prokop et al. 2017).

The main apparent difference between Xulsigia gen. nov. and all other Aphidomorpha is the presence of two strong veins emerging anteriorly from a straight stem of $\mathrm{CuA}$. But as noted above, the first of these veins is emerging as a secondary vein and is less convex than $\mathrm{CuA}$, unlike the second one that is a real fork of $\mathrm{CuA}$. We hypothesize that the first branch is in fact a branch of the median vein that is captured by $\mathrm{CuA}$ and re-emerges distally, while the second part of MP separates from radius much more distally. Thus MP has three branches as in Pincombeomorpha Shcherbakov, 1990 (Boreoscytidae, Pincombeidae, Simulaphididae), and $\mathrm{CuA}$ has two distal branches (areola postica). The important difference with these families is that the most basal branch of MP is still captured by the stem of $\mathrm{CuA}$ while there is a second distal branch of MP (itself forked) that emerges from radius independently from $\mathrm{CuA}$. The development of the median area in Xulsigia is remarkable, found only in the Pincombeomorpha, but not observed in known Aphidomorpha. Another difference from the Simulaphididae is the forked RP in Xulsigia. The shape of the pterostigma in Xulsigia is similar to that of Simulaphis, with a distinct posterior curvature of RA and a basal closure by a short apical part of ScP. 
Xulsigia karetsa sp. nov. corresponds to a new family Xulsigiidae fam. nov., that we place provisionally in the Pincombeomorpha. This group is diagnosed by set of characters (Shcherbakov 2007: 48, his use of veins names in square brackets): forewing with RP [RS] originating well before pterostigma, convex up to nodal line and concave beyond it; nodal line crossing RP [RS]; MP [M] and CuA forming a short common stalk; claval vein(s) remote from posterior margin, $\mathrm{Pcu}+\mathrm{A}_{1}[\mathrm{Pcu}+1 \mathrm{~A}]$ entering margin before claval apex. Any of these characters is apomorphic (Gavrilov-Zimin et al. 2015), and the group is probably paraphyletic. Remark. This fossil Sternorrhyncha is remarkable for its very large and petiolate wing, superficially resembling that of a fly of the family Ptychopteridae. Extant Sternorrhyncha are generally smaller insects, thus it would appear surprising to have such a large fossil taxon. But we have to keep in mind that such phenomena are known in other insect clades (e.g., the giant Meganeuridae have wing span ca. 10 times larger than extant Odonata).

High level nomenclature in Sternorrhyncha. There are several misunderstandings and unclears in concepts and contents of various groups placed in Sternorrhyncha. The groups as aphids in broad sense, coccids, or scale insects in broad sense are often united, but little attention was given in these statements to the fossil taxa. Schlee (1969) made the first attempt to unite aphids and scale insects, proposing the group named Aphidiformes to unite Aphidina (i.e. aphids, adelgids and phylloxerids) and Coccina (i.e. coccids, scale insects) - these names were used as chresonyms, without author's attributions. The name Aphidina was firstly introduced by Burmeister (1835: 85), but the group contained not exclusively aphids. This opinion was later used by Shcherbakov (2007), but with introduction of another chresonym 'Aphidinea Handlirsch, 1903 sensu lato' for this unit, ranked by him as suborder and with inclusion to it the fossil groups as Pincombeomorpha. Handlirsch (1903: 738) proposed a name Aphidoidea as suborder to contain only aphids, and another suborder Coccoidea (scale insects). Beier (1938: 
2426, 2427) first introduced the name Aphidinea (ranked as suborder), exclusively for aphids, adelgids, and phylloxerids, and in the same sense used by Shaposhnikov (1964: 489). Therefore, the content of the group named 'Aphidinea Handlirsch, 1903 sensu lato' was enlarged and redefined by Shcherbakov (2007: 48), with placement within extinct Pincombeomorpha, Aphidomorpha and Coccomorpha s. str (another chresonym explained below). Shcherbakov (2007: 51) used chresonym - 'Coccomorpha Fallén, 1814, sensu lato' for the group containing scale insects and extinct superfamily Naibioidea Shcherbakov, 2007. Fallén (1814: 3, 23) introduced name 'Coccides' (as family). Chou (1963: 592) introduced the name Coccomorpha (ranked as suborder) for scale insects. Williams (1969) presented several family-group names based on the genus Coccus Linnaeus, 1758. The use of name Coccomorpha was recently discussed by Williams \& Hodgson (2014). However, the name Coccomorpha was firstly used by Rübsaamen (1899: 534), for a new genus of cecidomyiid fly, still available for nomenclature as generic synonym of Rhizomyia Kieffer, 1898. Generic name Coccus Linnaeus, 1758 is based

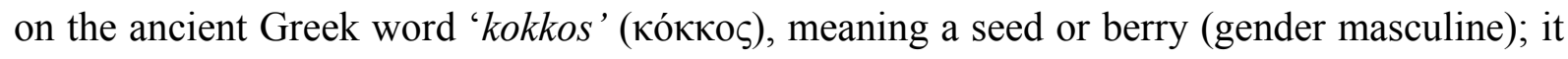
should be used under second declension, i.e. coccus, cocci. Following the " $\sim$ morpha" principle for naming the units above family-groups, and unification of endings of them, the name Coccidomorpha was proposed by Heslop-Harrison (1952: 688).

To avoid confusion with Coccomorpha Rübsaamen and contrary to opinion of Williams \& Hodgson (2014) the name Coccidomorpha Heslop-Harrison, 1952 should be conserved. Recently Kluge (2010: 248) proposed another name for the group uniting aphids and scale insect (but without fossils) - Aphidococca. This name was adopted by Gavrilov-Zimin et al. (2015: 336), but omitted in their classification proposal (Gavrilov-Zimin et al. 2015: 336-337). In the same list and paper, the fossil groups were not listed or treated taxonomically. But in their Figure 1, entitled "Phylogeny of Aphidococca placed on geochronological scale", the fossil groups Archescytinoidea, Pincombeoidea, and Naibioidea were figured together with the 
recent superfamilies. This leads to further confusion in taxonomic and nomenclatorial treatment and content of this evolutionary lineage.

\section{Acknowledgements}

We wish to thank Guy Marson, Guy Kronz and Dr. Simon Philippo (all Musée national d'histoire naturelle, Luxembourg), for their help with the preparation of the specimen and the photographs (both macro and SEM).

\section{References}

Ansorge, J. 1996. Insekten aus dem Oberen Lias von Grimmen (Vorpommern, Norddeutschland). Neue Paläontologische Abhandlungen, 2, 1-132.

Ansorge, J. 2003. Insects from the Lower Toarcian of Middle Europe and England. Acta Zoologica Cracoviensia, 46 (suppl. - Fossil Insects), 291-310.

Aristov, D. S. 2015a. New Gryllones (Insecta) from the Permian of Russia. Paleontological Journal, 49 (12), 1310-1333.

Aristov, D. S. 2015b. Classification of the order Eoblattida (Insecta: Blattidea) with description of new taxa. Far Eastern Entomologist, 301, 1-56.

Amyot, C.-J.-B. \& Audinet-Serville, J.-G. 1843. Histoire naturelle des insectes. Hémiptères. Librairie Encyclopédique de Roret, Paris, 1-675.

Becker-Migdisova, E. E. 1949. [New Permian family of the Boreoscytidae and the phylogeny of the Hemipteran ancestors.]. Trudy Paleontologicheskogo Instituta Akademii nauk SSSR, 20, 171-182.

Becker-Migdisova, E. E. \& Aizenberg, E.E. 1962. Infraotryad Aphidomorpha. [Infraorder Aphidomorpha]. 194-199. In: Rohdendorf, B. B. (ed) Osnovy palontologii. 
Chlenistonogie. Trakhei"nye i Khelicerovye. [Fundamentals of Palaeontology.

Arthropoda. Tracheata and Chelicerata.] 9. Izdatel'stvo Akademii Nauk SSSR, Moscow.

Beier, M. 1938. 29. und zugleich letzte Ordnung der Pterygogenea: Homoptera $=$ Pflanzensauger (Zikaden und Pflanzenläuse). In: Kükenthal, W. (ed.) Handbuch der Zoologie, 4 (2), Berlin, pp. 2205-2456.

Bode, A. 1953. Die Insektenfauna des Ostniedersächsischen oberen Lias. Palaeontographica, (A), 103, 1-375.

Burmeister, H. 1835. Schnabelkerfe. Rhynchota. In: Handbuch der Entomologie. 2. Abt. 1. Berlin. pp. 1-404.

Chou, Io 1963. Some viewpoints about insect taxonomy. Acta entomologica sinica, 12 (5-6), 586-596 (in Chinese with English abstract).

Delsate, D., Godefroit, P., Stomp, N., Faber, A., Massard, J.A., Maubeuge, P.-L., Boulvain, F. \& Roche, M. 1999. Remarques sur l'article de Henrotay, Marques, Paicheler, Gall and Nel (1998): "Le Toarcien inferieur des régions de Bascharage et de Bettembourg (Grand-Duché du Luxembourg) : évidences paléontologiques et sédimentologiques d'environnements restreints proches de l'émersion". Bulletin des Académies et Société Lorraines des Sciences, 38, 15-27.

Delsate, D., Henrotay, M. \& Godefroit, P. 1992. Présence d'insectes dans le Toarcien inférieur de la Belgique. Bulletin de la Société Belge de Géologie, 100, 147-153.

Dittrich, D. 1993. Erläuterungen zur geologischen Karte von Luxemburg 1:25 000, Blatt $N^{\circ}$ 11 Grevenmacher und Blatt No 13 Remich. Bulletin de la Carte Géologique du Luxembourg, 16, 1-55.

Fallén, C. F. 1814. Specimen novam Hemiptera disponendi methodum exhibens. Publicae disquistioni subjicit Magnus Rodhe - Lundae. Litteris Berlingianus, 1-26. 
Fossilworks Gateway to the Paleobiology Database 2017. Internet site: http://fossilworks.org/

Gavrilov-Zimin, I. A., Stekolshchikov. A. V. \& Gautam, D. C. 2015. General trends of chromosomal evolution in Aphidococca (Insecta, Homoptera, Aphidinea + Coccinea). Comparative Cytogenetics, 9 (3), 335-422. doi: 10.3897/CompCytogen.v9i3.4930. eCollection 2015.

Godefroit, P. 1994. Les reptiles marins du Toarcien (Jurassique inférieur) belgoluxembourgeois. Mémoires pour Servir à l'Explication des Cartes Géologiques et Minières de la Belgique, 39, 1-98.

Guan, Zhaoying, Prokop, J., Roques, P., Lapeyrie, J. \& Nel, A. 2015. Revision of the enigmatic family Anthracoptilidae enlightens the evolution of Palaeozoic stemdictyopterans. Acta Palaeontologica Polonica, 61, 71-87.

Handlirsch, A. 1903. Zur Phylogenie der Hexapoden. Sitzungberichte der Akademie der Wissenschaften in Wien, Matematische-Naturwissenshaftlische Klasse, 112 (1), 716738.

Hanzo, M. 1978. A propos des nodules carbonates du Toarcien inférieur de la région de Bettembourg (Luxembourg). 103ème Congrès de la Société Scientifique de Nancy, 4, $343-349$.

Hanzo, M. 1979. Milieu de dépôt et évolution diagénétique des argilites toarciennes d'après l'étude de nodules carbonatés des "schistes carton" de Bettembourg (Grand-Duché du Luxembourg). Sciences de la Terre, 23, 45-49.

Heie, O.E. \& Wegierek, P. 2009. Diagnoses of the higher taxa of Aphidomorpha (Hemiptera Sternorrhyncha). Redia, 92, 261-269.

Henrotay, M., Marques, D., Paicheler, J.-C., Gall, J.-C. \& Nel, A. 1998. Le Toarcien inferieur des régions de Bascharage et de Bettembourg (G.D. Luxembourg): évidences 
paléontologiques et sédimentologiques d'environnements restreints proches de l'émersion. Geodiversitas, 20, 263-284.

Hermoso, M., Delsate, D., Baudin, F., Le Callonnec, L., Minoletti, F., Renard, M. \& Faber, A. 2014. Record of Early Toarcian carbon cycle perturbations in a nearshore environment: the Bascharage section (easternmost Paris Basin). Solid Earth, 5, 793-804.

Heslop-Harrison, G. 1952. LXXII.-Preliminary notes on the ancestry, family relations, evolution and speciation of the Homopterous Psyllidae.-II. Annals and Magazine of Natural History Series 12, 5 (55), 679-696, doi:10.1080/00222935208654339

Huang, Di-Ying, Bechly, G., Nel, P., Engel, M.S., Prokop, J., Azar, D., Cai, Chen-Yang, van de Kamp, T., Staniczek, A.H., Garrouste, R., Krogmann, L., dos Santos Rolo, T., Baumbach, T., Ohlhoff1, R., Shmakov, A.S., Bourgoin, T. \& Nel, A. 2016. New fossil insect order Permopsocida elucidates major radiation and evolution of suction feeding in hemimetabolous insects (Hexapoda: Acercaria). Scientific Reports, 6 (23004), $1-9$.

Kieffer, J. J. 1898. Synopse des cécidomyies d'Europe et d'Algérie décrites jusqu'à ce jour. Bulletin de la Société d'Histoire Naturelle de Metz, 20, 1-64.

Kluge, N. Yu. 2010. Paradoxical molting process in Orthezia urticae and other coccids (Arthroidignatha: Gallinsecta) with notes on systematic position of scale insects. Zoosystematica Rossica, 19, 246-271.

Linnaeus, C. von 1758. Systema Naturae per regna tria naturae secundum classes, ordines, genera, species cum characteribus, differentiis, synonymis, locis. Ed. decima reformata. Holmiae, Laur. Salvii, 1, 1-823.

Martynova, O. M. 1952. [Permian lacewing (Neuroptera) from the U.S.S.R.] Trudy Paleontologiceskogo Instituta Akademii nauk SSSR, 40, 197-237. [in Russian]. 
Maubeuge, P. L. 1973. Insecte et Stelléroïdes du Jurassique inférieur luxembourgeois. In: Histoire Naturelle du Pays du Luxembourg. Géologie. Publications du Musée National d'Histoire Naturelle, Luxembourg, 2 pp.

Nel, A., Prokop, J., Nel, P., Grandcolas, P., Huang, Di-Ying, Roques, P., Guilbert, E., Dostál, O. \& Szwedo, J. 2012. Traits and evolution of wing venation pattern in paraneopteran insects. Journal of Morphology, 273, 480-506.

Nel, A. \& Weis, R. 2017. A new Early Jurassic damselfly from the Grand Duchy of Luxembourg (Odonata: Campterophlebiidae). Alcheringa, 41, 378-382.

Prokop, J., Krzemiński, W., Krzemińska, E., Hörnschemeyer, T., Ilger, J.-M., Brauckmann, C., Grandcolas, P. \& Nel, A. 2014. Late Palaeozoic Paoliida is the sister group of Dictyoptera (Insecta: Neoptera). Journal of Systematic Palaeontology, 12, 601622.

Prokop, J., Pecharová, M., Garrouste, R., Beattie, R., Chintauan-Marquier, I. C. \& Nel, A. 2017. Redefining the extinct orders Miomoptera and Hypoperlida as stem acercarian insects. BMC Evolutionary Biology, 17, 1-20.

Rübsaamen, E. H. 1899. Ueber die Lebensweise der Cecidomyiden. Biologisches Centralblatt, 19, 529-549.

Schlee, D. 1969. Sperma-Übertragung (und andere Merkmale) in ihrer Bedeutung für das phylogenetische System der Sternorrhyncha (Insecta, Hemiptera). Phylogenetische Studien an Hemiptera. 1. Psylliformes (Psyllina and Aleyrodina) als monophyletische Gruppe. Zeitschrift für Morphologie der Tiere, 64, 95-138.

Shaposhnikov, G. Kh. 1964. Suborder Aphidinea. In: Bey-Bienko, G.Ya. (ed.) Opredelitel nasekomykh evropeiskoi chasti SSSR, I. [Suborder Aphidinea. Keys to the Insects of the European Part of the USSR, I. Nauka, Moscow-Leningrad, 489-616 (in Russian). 
Shcherbakov, D. E. 1990. Extinct four-winged ancestors of scale insects (Homoptera, Sternorrhyncha). Proceedings of the 6th International Symposium on Scale Insects Study in Cracow, August 6-12, 1990, Agricultural University Press, Cracow, part 2, 23-29.

Shcherbakov, D. E. 2007. Extinct four-winged precoccids and the ancestry of scale insects and aphids (Hemiptera). Russian Entomological Journal, 16, 47-62.

Storozhenko, S. Yu. 1998. Sistematika, filogeniya i evolyutsiya grilloblattidovykh nasekomykh (Insecta: Grylloblattida) [Systematics, phylogeny and evolution of the grylloblattids (Insecta: Grylloblattida).] Dal'nauka, Vladivostok, 1-207 (in Russian).

Szwedo, J. 2011. Coleorrhyncha (Insecta: Hemiptera) of the European Jurassic and the first Progonocimicidae from the Lower Toarcian of Luxembourg. Volumina Jurassica, 9, 3 20.

Tillyard, R. J. 1922. Some new Permian insects from Belmont, N.S.W., in the collection of Mr John Mitchell. Proceedings of the Linnean Society of New South Wales, 47, 279-292.

Tillyard, R. J. 1937. Kansas Permian Insects, Part 18: The Order Embiaria. American Journal of Science, (5), 33, 241-251.

Verhoeff, C. 1893. Vergleichende Untersuchungen über die Abdominal-segmente der weiblichen Hemiptera-Heteroptera und Homoptera. Entomologisches Nachrichtenblatt, 19, 369-378.

Whalley, P. E. S. 1985. The systematics and palaeoegeography of the Lower Jurassic insects of Dorset, England. Bulletin of the British Museum (Natural History), Geology, 39, 107187.

Williams, D. J. 1969. The family-group names of the scale insects (Hemiptera: Coccoidea). Bulletin of the British Museum (Natural History) Entomology, 23, 317-341. 
Williams, D. J. \& Hodgson, C. J. 2014. The case for using the infraorder Coccomorpha above the superfamily Coccoidea for the scale insects (Hemiptera: Sternorrhyncha). Zootaxa, 3869, 348-350. doi: 10.11646/zootaxa.3869.3.9

Figure 1. Fig. 1. A, Geographic map of the Grand Duchy of Luxembourg (L) with indication of the study area; B, Close-up of the study area (region of Bascharage), with indication of the insect-bearing sites; C, Simplified stratigraphic log of the Bascharage section (adapted from Hermoso et al. 2014) with indication of the insect-bearing limestone bed.

Figure 2. Xulsigia karetsa gen. et sp. nov., holotype TV045 (a+b), photograph of complete wing. Scale bar $=5 \mathrm{~mm}$.

Figure 3. Xulsigia karetsa gen. et sp. nov., holotype TV045 $(\mathrm{a}+\mathrm{b})$, photograph of complete wing under alcohol. Scale bar $=5 \mathrm{~mm}$.

Figure 4. Xulsigia karetsa gen. et sp. nov., holotype TV045 $(\mathrm{a}+\mathrm{b})$, reconstruction of complete wing with interpretations of main veins. Scale bar $=2 \mathrm{~mm}$.

Figure 5. Xulsigia karetsa gen. et sp. nov., holotype TV045 $(\mathrm{a}+\mathrm{b})$, photograph of wing apex. Scale bar $=1 \mathrm{~mm}$.

Figure 6. Xulsigia karetsa gen. et sp. nov., holotype TV045 (a+b), photograph of wing base. Scale bar $=1 \mathrm{~mm}$. 


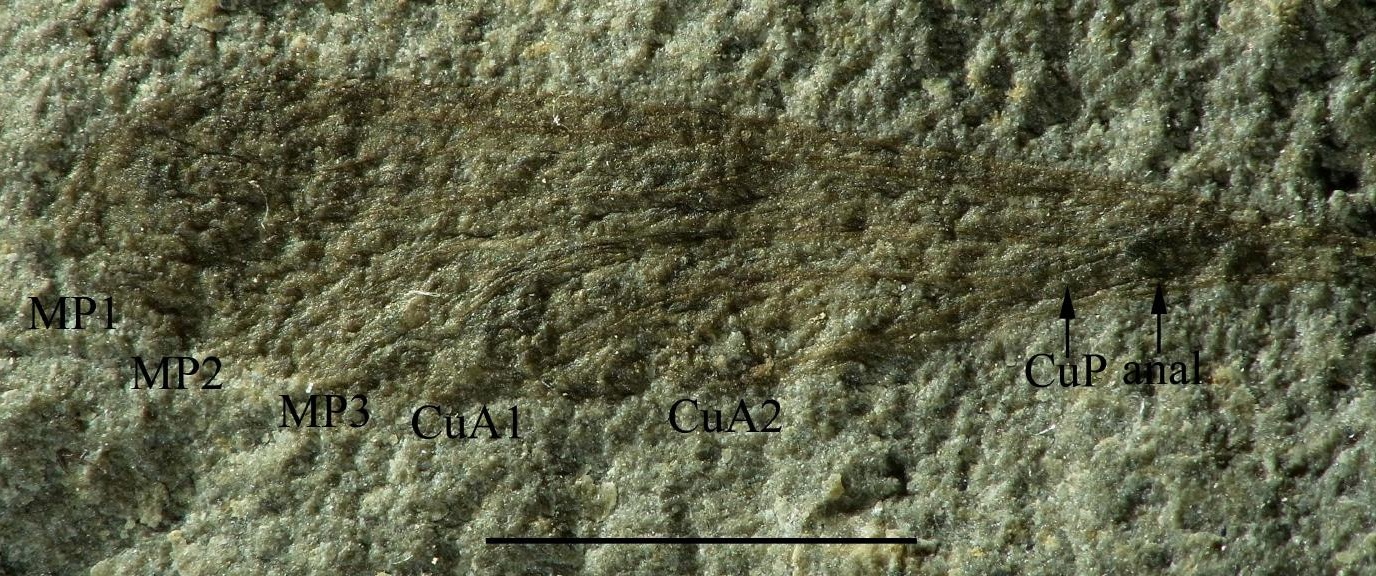




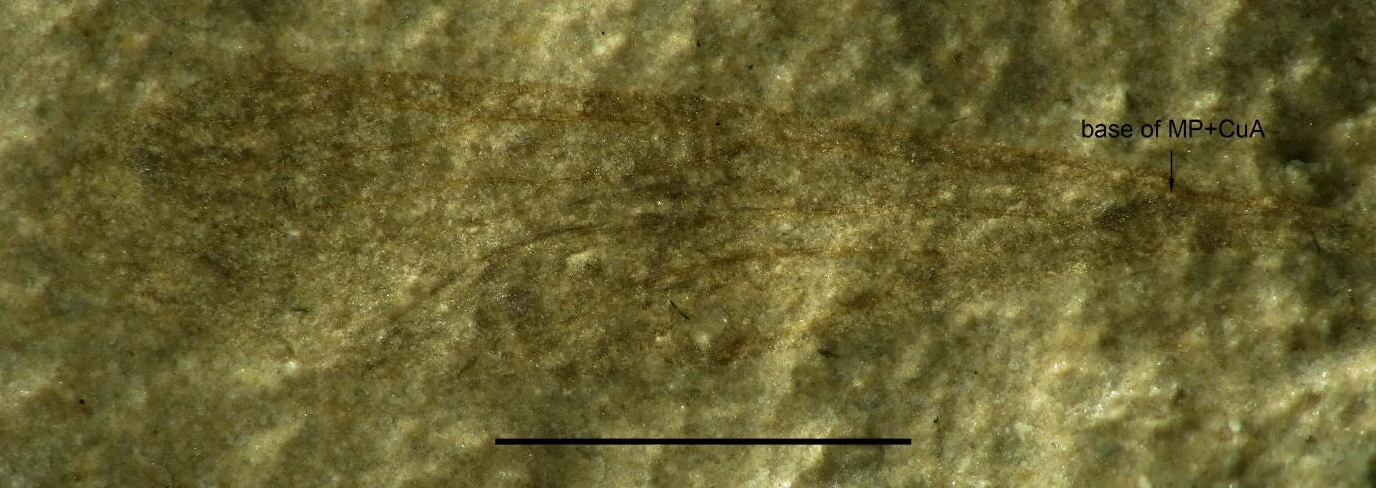





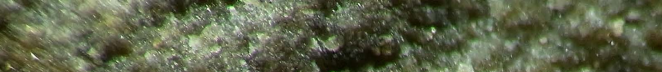

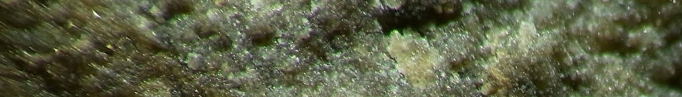

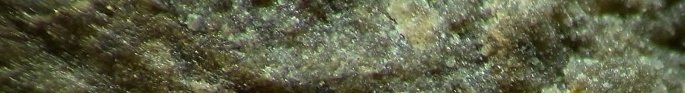

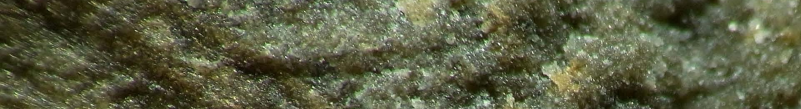
S.t. $-5 \mathrm{NeP3}$ CuAl
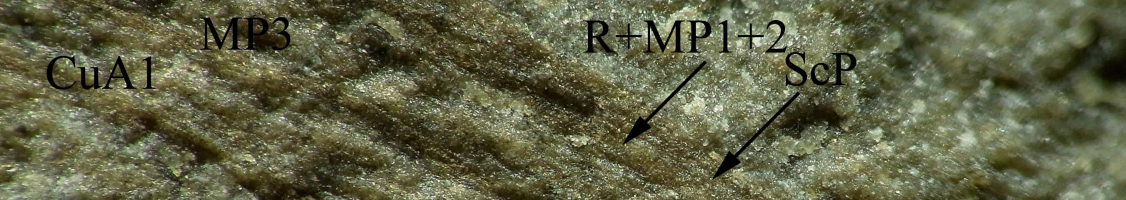

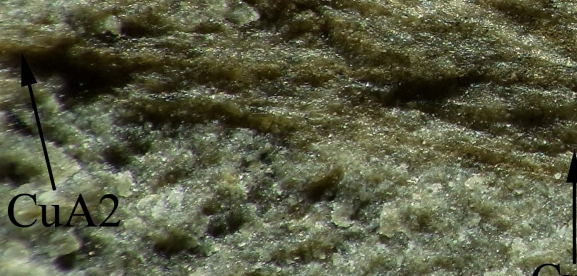

$\mathrm{CuP}$
posteubital vein
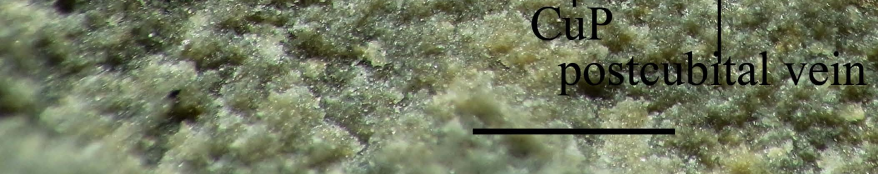

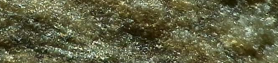
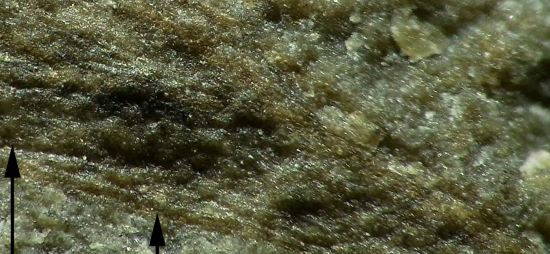